\title{
Naming and nurturing reality from a heart renewed by grace
}

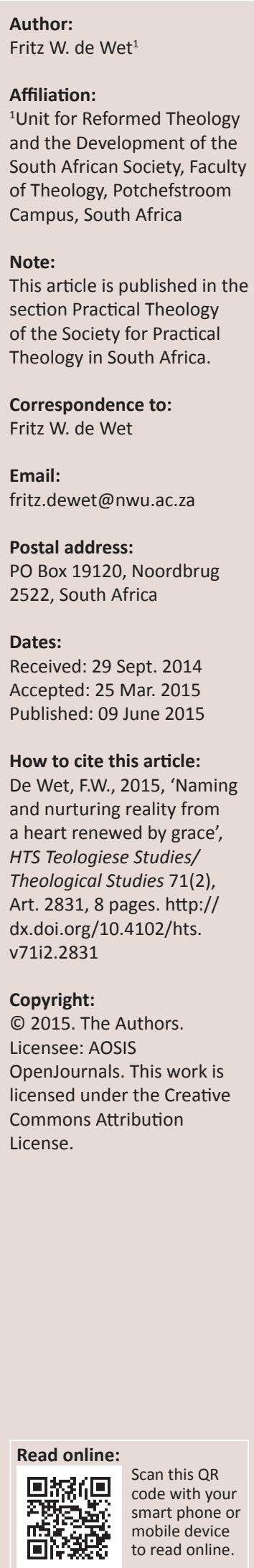

This contribution investigates the unbearable tension between the homiletical act of naming reality (with the promise of exposing, challenging and/or triggering creative forces in it) on the one hand, and neglecting this same reality on the other hand, thereby causing it to return to an ignored, unchallenged and degenerated state. The author focuses on tension fields that are generated when preachers embark on the activity of naming realities in their proximate contexts and how they position, withdraw or distance themselves in a certain way when problematic elements (for instance the glaring and seemingly unbridgeable inequality in the situation of Dalits) are opened up by the act of naming. By means of a theological reflection on the renewal of the heart by God's act of grace in Christ, the author attempts to identify key markers for a homiletic theory that will be able to link the act of naming reality with the act of nurturing (rather than neglecting) this named reality.

\section{Introduction}

Speaking and acting out prophetic words of redemption in a world in which patterns of marginalisation, contempt and deprivation are deeply entrenched and kept in place by dominant systems ${ }^{1}$ proved to be no easy task.

Preachers, who meet with resistance against the far-reaching changes implied by their prophetic witness, are all too familiar with debilitating challenges like the following:

- a deep feeling of powerlessness and inadequacy in the face of mountain-like challenges

- a discouraging feeling that it is better to remain silent than to give false hope

- a history of being part of the problem (authoritarian, marginalising language in a postcolonial setting) and therefore reluctance to speak boldly

- fear in the face of a system-challenging message being met with opposition (cf. Tubbs Tisdale 2010:10-20).

At its heart, this tension field involves speaking truthful words, not later found to be lacking integrity. Naming an aspect of reality ${ }^{2}$ implies the boldness of attempting to voice the true nature of this particular manifestation and our relation to it and looking the consequences in the face. The prophetic rhetoric involved in an act of naming a situation of marginalisation and social injustice, for instance, is designed to break the bubble, to make contact with the facts on the ground that God is here and the neighbour is here (Brueggemann 2014:23). Once something that has remained 'unspoken' becomes spoken, you have to face the consequence of what you have said about it; otherwise your words become empty and untruthful. Neglecting reality involves allowing the true nature of a situation to be hidden from disclosure and therefore creating the illusion that it is not in need of decisive action. Neglecting reality also involves the unbearable scenario when a named reality proves to be in need of serious action, but is allowed to disintegrate into an irreparable state.

The dynamics of the aforementioned problem field can clearly be traced in the theme that was chosen for Societas Homiletica's 11th international conference: 'Preaching vulnerability: Naming

\footnotetext{
1.Brueggemann (2014) describes the dominant ideology (as it manifested in Old Testament Israel's royal-temple theology and echoed in the ideology of exceptionalism in contemporary US society) as follows: 'The dominant ideology believes, in its power and its wisdom, that you can compartmentalize and privatize; that you can declare unwelcome social reality inoperative and irrelevant; that you can separate economics from neighborliness; that you can enjoy chosenness and thereby avoid the demands of the others' (p. 23).

2.One's presuppositions in viewing reality and the effects this will have on naming reality need to be considered. Dingemans (2010:107) illustrates how modern western thinking significantly changed the way we - who find ourselves embedded in this particular culture tend to view reality. In premodern times the primacy was with the spiritual world (the ideal world) in its influence on the physical world. In modern thinking a 180-degree turn was made: the natural world and the empirical observations that can be made in this natural world, becomes the only verifiable norms for our thinking and behaviour. The 'spiritual word' came to be seen as a construct of human thinking or imagination, not having an objective reality of its own (cf. Colson \& Pearcy 1999:ix). The author, however, works with a theological presupposition that relinks with premodernity in the sense that the 'spiritual word' and 'physical world' are viewed to be different aspects of one relational objective reality; a reality in which the knowledge of our place in this world is intrinsically linked with how God makes Godself known (cf. Zimmermann 2004:317). The reality of the world we live in is then viewed as an objective environment that was brought into existence for a particular purpose. From a Christian perspective this particular origin and purpose are then interpreted to be intrinsically linked with the work of the triune God, the Creator, Redeemer and Consummator.
} 
and neglecting reality'. ${ }^{3}$ At its heart this problem field has to do with the unbearable tension between naming (exposing, challenging and/or triggering creative forces in) reality on the one hand, and neglecting reality on the other hand, thereby causing it to return to an ignored, unchallenged and degenerated state. In her introductorily reflection on the above-mentioned conference theme, Dawn Ottoni-Wilhelm (n.d.) summarises the homiletic challenges that have to be faced in the dynamics at play in this problem field as follows:

\begin{abstract}
... it is the preacher's responsibility to name that of God among us as well as that which we have neglected. Whether we are worried about our own vulnerability or have ignored the vulnerability of others, we must name what has become 'unspeakable' and recognize what we have neglected in our preaching so that we may be free to speak the Spirit's free, redeeming words for the church and world.
\end{abstract}

Ottoni-Wilhem's statement reminds us that the act of naming does not have to end in a futile attempt at getting to grips with a problematic element in reality, only to be restrained by our own vulnerability and the seemingly unconquerable vulnerability others find themselves in. ${ }^{4}$ The act of naming does not necessarily have to end in an act of negligence. And this, we believe, is possible because God's redeeming presence can be visualised and voiced even in the most distorted proximate contexts. From a theological anthropological perspective this faith-visualisation of the redeeming presence of God works with the presupposition that humanity can be regenerated by the grace of God right up till the core of our existence. The act of naming can proceed from a vulnerable heart that is in the process of being renewed by God's grace. In the act of naming, a reality can be visualised in which wounded, dejected and hardened hearts can be healed and opened up to a hopeful existence by God's regenerative grace.

The purpose of this contribution, then, is to focus on a particular aspect of our human vulnerability that plays a significant role in the extent to which we are able to commit ourselves to certain actions with integrity and are able to embrace new possibilities for our existence in change-resisting proximate contexts. The aspect that we have in mind here is the metaphorical usage of heart $t^{5}$ in its vulnerability; in its tendency

3.The Societas Homiletica is an academic and international society for teachers and researchers of preaching and homiletics. Its main activity is a biannual international conference and the publication of its proceedings.

4.Theological anthropologist, David H. Kelsey's (2009a:537) description of human vulnerability reflects the intrapersonal as well as interpersonal elements in the following way: '... creaturely personal bodies that are finite centers of energy, limited, both internally in respect to the range and energy and externally in respect to the way they are impinged on by other creatures and impinge on them respect to the way they are impinged on by other creatures and impinge on them
in return, inherently vulnerable to damage, violation, disintegration, and death.' The vulnerability of these creaturely personal bodies constitutes part of the multiple dimensions of our existence that God relates to. According to Kelsey, God draws human creatures into borrowed time by relating proleptically to them in eschatological blessing in the resurrection of the crucified Jesus in the midst of thei ambiguous and distorted proximate contexts.

5.When referring to heart the author does not have the physical organ inside the human body in mind. It is rather the metaphorical sense that is intended. When we refer to heart in our daily metaphoric use of this concept (for instance referring to someone as having a black heart' or a 'heart of gold' or creative efforts as 'having a heart' or 'lacking a heart'), what appear to be conveyed are some particular dimensions of being and feeling that can be put into living in certain ways (Pearmain 2001:75). When Paul refers to kardia (heart) in his anthropological terminology, he clearly has the metaphorical sense in mind. Linking with the Old Testament usage, the heart is seen to be the deepest seat from which thought, will and action usage, the heart is seen to be the deepest seat from which thought, will and action
proceed. Kardia as an instrument of one's ego and can either be bad (as the source to become hardened, confining the expressions of existence to self-centredness in the process; and in its tendency to become half-hearted and divided, clouding the clarity of vision that is needed for uncompromising change in the process.

The core questions that we ask in this contribution amount to the following: To what extent will a theological reflection on the renewal of the heart be able to identify key markers for a homiletic theory that attempts to link the act of naming reality with the act of nurturing (rather than neglecting) this named reality? What will be the effect of a heart, that is in the process of being renewed, on the prophetic vision with which a preacher and the prophetic communities that flow from preaching approach reality?

In order to address these questions the following aspects will be considered:

- What it entails to name reality.

- Naming and neglecting reality from a compromised heart.

- Perspectives on renewal of heart from canonical Holy Scripture.

- Naming and nurturing reality from a heart in the process of being renewed by God's grace.

\section{What it entails to name reality}

In this section we shortly reflect on the essence of the act of naming reality.

Insights from language theory help us to understand how we use language to name, order and codify our world, in the process creating and altering perceptions. ${ }^{6}$ Armstrong and Fontaine $(1989: 8,9)$ reflect on the power involved in the naming process. By naming something, a place is actively carved out for it to occupy in the perceptions of the one who names. The act of naming and the power involved in this act, however, also have a social dimension. A group of likeminded people (or the individual who represents them) can take on the ability to exclude or include, burden or empower other individuals by the act of naming them.

The power of naming (in the process of taking advantage of the inscriptive, classificatory nature of language) can become an act of 'arche-violence' that divides people into different categories, thereby separating them from each other and heightening the potential for conflict and violence. In this sense language can be seen to lend itself to violence, with critical language having the potential to become the most violent of all (Armstrong \& Fontaine 1989:9; Siebers 1988:9, 83).

Our interest, as practical theologians especially lies in the action field that is generated where the act of naming takes place

\footnotetext{
of bad desires and lusts that proceed from the inner being, polluting expressions of life with impurity as in Rom 1:24) or it can be the seat of good desires and belief that find expressions in the confessing words and actions of a justified believer (Rom 10:1, 10; Witherington 1994:291).
}

6.Cf. for example Umberto Eco (1976), Michel Foucault (1970) and Roland Barthes (1972) for various perspectives on how we use language in the process of perception-creation or alteration. 
and its consequences play out. We will, thus, focus on action fields (and tension fields) that are generated when people enter into critical discourse with each other, naming realities in the process and positioning themselves in the tension field that is generated when problematic elements (for instance glaring inequality) are opened up by the act of naming.

In this regard, Paulo Freire, (Brazilian educator, philosopher and leading advocate of critical pedagogy) made a significant contribution in describing the essence of what is triggered in the interhuman action field when the act of naming takes place during discourse.

In his influential work, Pedagogy of the oppressed, Freire (2007:87) identifies two dimensions in authentic discourse, namely that of reflection and that of action; the process of naming reality and the process of changing reality. There is no true word that is not at the same time a praxis. Thus, to speak a true word, is to transform the world. Reflection alone is insufficient because it implies mere verbalism. Action alone is similarly inadequate, mere activism, where the energy for choosing exists apart from critical awareness and direction. Naming always entails transformation because the process of naming renders the world problematic, a choice from among possible choices and therefore a limitation to be challenged. At the same time, action, the process of transforming, always entails a new naming, because the emergence of reality is only possible through a struggle to articulate.

Freire $(2007: 88,89)$ sees dialogue as the:

encounter in which the united reflection and action of the dialoguers are addressed to the world, which is to be transformed and humanized, this dialogue cannot be reduced to the act of one person's 'depositing' ideas in another; nor can it become a simple exchange of ideas to be 'consumed' by the discussants. Because dialogue is an encounter among women and men who name the world, it must not be a situation where some name on behalf of others [and dominate them in the process]. (pp. 88, 89)

Since naming and transforming the world is an act of creation, this dialogue cannot be authentically entered with a motive to merely impose the own (unchanged and unchallenged) view of truth on the other party, without being committed to a mutual search for truth. The only kind of domination implicit in authentic dialogue is that of the world by the dialoguers; it implicates a conquest of the world for the liberation of humankind.

What are the implications of these ideas for a theological reflection on naming and neglecting reality? These insights from language philosophy and Freire's critical pedagogy provide thought-provoking perspectives for qualifying the dialogical element and weighing the character of authenticity in communicative acts like preaching. When a preacher names a problematic element in the world shared by the listeners (for instance the unbearable praxis of being marginalised and despised by the prevailing dominant system that drives that particular society), without committing to transformative action, no authentic discourse can take place. When preachers, in the process of naming a problematic element, impose their own view on the others (a view possibly qualified by rigid fear, doubt and despondency), the problem can be coded or categorised as unsolvable and no transformative creativity can be unleashed by the homiletic event. An element of violence can enter the naming process when the preachers impose a problematic element on their listeners. Listeners (both on the so-named privileged and unprivileged sides of the spectrum) can feel that they are categorised in such a way that they irreversibly become part of the problem and are violently estranged from their fellow members of the human race. This, for example can make the privileged feel that they are irredeemably guilty of exploiting the marginalised, or can make the unprivileged believe that the marks of their despised position and marginalisation cannot be dissolved and that their only option is self-pity.

In the next section the act of naming and neglecting reality in preaching is discussed, with thoughts and examples from homiletic reflection that illustrate how difficult it is to speak a liberating word in a context where marginalisation, alienation and inequality are deeply entrenched in a particular human society. This discussion is done from a vantage point that focuses with particular interest on how the motives that flow from the core of humanity (the human heart) are involved in the tension field of naming and neglecting reality.

\section{Naming and neglecting reality from a compromised heart}

In this section the idea is to give descriptive accounts of what happens when preaching attempts to name reality, whilst not taking the active role of the heart into account. When an act of naming proceeds from a heart that is not sensitively attuned to God's vision for this world and not committed to the far-reaching change (transformation) that is implied by the Christian gospel, negligence will be the inevitable result; negligence that does double damage in the sense that the naming process presented itself as a disclosure of the true state of our reality and even created expectations for transformative change, only to let disclosure end in the violence of condemnation; and only to let the construction site of hope fall into disrepair and despair.

Childs (2003) sketches the all too familiar homiletic impasse that is created when the sermonic act of naming a problematic element in our reality renders the listeners (in this case the privileged) to be captives of the problem without empowering them with a vision for a way out of the problem:

The preacher went on and on. He battered us with statistics. We now know the exorbitant amount we spent on a variety of petty luxuries as compared with the relative pittance much of the World's population had at their disposal for the very essentials of life. The sharp-edged numbers revealing our tiny affluent minority's inordinately outsized share of global consumption cut deeply into the flesh of our consciences. The recitation of these statistics was calculated to convert us to the cause of justice. In the preacher's mind it seemed a good sermon in the best prophetic tradition. However, for most of us his diatribe produced only 
feelings of unresolved guilt. We were condemned, albeit justly, but not empowered. It was clear that we were part of the problem, but how could we possibly be a part of the solution? And when that question goes unanswered, feelings of guilt quickly turn to feelings of anger and resentment. (p. 35)

By naming the problem in such a way that the listeners get the message that they are categorised as part and parcel of an exploitive system (without imagining a viable alternative to this system together with the listeners), the word event degenerates into an extreme form of disempowering and denigrating violence, as Childs (2003) states:

When we instill either guilt or fear, we are simply pointing out moral frailty. Guilt is engendered when our moral failings are exposed to the critique of the moral law. Fear is engendered when punishments are attached to the violation of that law. The existence of a threat of penalty to strike fear in our hearts is simply a way of saying that if we don't threaten penalties, people will not do the right thing. This can be a self-fulfilling prophecy; though we may stay within the bounds of compliance, we can easily come to accept conflict and selfishness as normal. We are denigrated. We are not empowered. (pp. 36, 37)

Words that are exclusively shaped to instil fear and guilt and to keep selfishness in its comfortable (hidden) position position cannot be authentic words. Words like these create death rather than life. Words like these bear witness to the state of the heart from which they flow: a heart clouded and divided by fear and doubt; a heart that knows quite well what we should be against, but does not take care to open up the resources of life in order for it to flow freely into the unknown terrain of the kind of united humanity that God intends us to become. Words that name reality, but flow from a heart that is so compromised that it can only create an illusion of having disclosed reality prophetically, will not be able to be instrumental in liberating and humanising reality. Words flowing from a heart like this, can only fail regarding the essence of what true prophecy entails. Rather than becoming fulfilled words in the sense of bearing a kind of fruit that provides lasting health to the nations, these words can only accelerate disintegration and ultimately end in selfdestruction.

The other side of the spectrum in the dynamic field of naming reality involves the dialogue with the unprivileged in society. Indian Christian communities for example face the challenge of having to address the 'Dalit ${ }^{17}$-situation in such a way that deeply entrenched patterns of estrangement are being bridged in the process. Speaking about the injustice that the Dalits have to suffer due to their abused, exploited

\footnotetext{
7.The word Dalit comes from a Sanskrit root that is associated with things or people that are cut, split, crushed and destroyed. The present use of the word Dalit presumably goes back to the nineteenth century, when a Marathi social reforme and revolutionary, Mahatma Jyotirao Phule (1826-1890), used it to describe the 'Outcastes' and 'Untouchables' as the oppressed and broken victims of a casteridden Indian society. It should, however, be noted that Dalit does not carry the meaning of caste or low-caste or impurity in itself (as does some of the other more derogatory terms used to describe the standing of these particular people in more derogatory terms used to describe the standing of these particular people in Indian society). It rather refers to the condition of brokenness to which this group of people has been reduced by social convention. For people who are subjected to abject poverty and experience that they are treated as polluted human beings, the name Dalit can even become a name they choose to give themselves, constantly reminding themselves of the age-old oppression that they still have to bear and serving as a communal expression of hope to recover their past self-identity (Sandangi 2008:3).
}

and marginalised position in society, can become empty rhetoric when no commitment is made to reimagine a truly integrated society, and reality is consequently neglected. Gnanavaram (1999), speaking from a Dalit perspective, made the following observation at the 4 th biennial conference of Societas Homiletica (that was held 27 February - 04 March 1999 at Virginia Theological Seminary, Washington, DC):

The worst crime the caste-people has committed against us has been to teach us to hate and pity ourselves. The non-Dalits have succeeded in planting within us self-pity and hatred because they have power and we Dalits are powerless. Their success is further enhanced by the institution of caste and the ideology of untouchability. The Dalit Christian reality is not very different from the general Dalit situation. We Christian Dalits are outcast in the Christian churches. (p. 50)

A case of hidden violence can occur when the problems involved in the Dalit situation are named in such a way, that Dalits are made to believe that they are mere passive objects of pity who cannot else than be kept in their allotted place. Words that engender this hidden form of violence, causes double hurt, as it is supposed to come from the mouths of people who present themselves as bearers of the Word of the One, who promised to makes all things new. The double hurt that words like these violently open up and their failure to deal with the present reality are reflected in Alfred Stephen's (n.d.) initial thoughts on the Dalit situation. This was expressed in his presidential welcoming message prior to the 11th International Conference of Societas Homiletica that took place in Madurai (India) from 25 to 30 July 2014:

The Christian Dalits undergo more sufferings and discriminations, both from within the church and outside and thus they suffer multi-faceted alienation. Their stigma continues and discriminations intensified and doubled. The irony is that their socio-cultural reality does not seem to be a matter of concern both in doing theology and in preaching. The main contention is that preaching comfortably has eluded taking the socio-cultural reality of the Dalits into consideration in the hermeneutical process, thus making preaching of the gospel difficult and the message irrelevant to the Dalits as it has failed to reflect their social and cultural reality.

Stephen's initial thoughts point out the important place of the current social-cultural situation people find themselves in, in naming reality. The gospel's impact on naming reality cannot be reduced to imagining a futuristic, spiritualised world that is isolated from human life and human community in its present state. But even attempts at contextualising theology and including the element of liberation in the hereand-now situation does not necessarily introduce elements of authenticity and transformative integrity to the act of naming. Rajkumar (2010) queries the 'practical efficacy' of contemporary Christian Dalit theology ${ }^{8}$ in the following way:

Christianity in India in the twenty-first century is confronted with a paradoxical situation. On the one hand we have the

8.Christian Dalit theology professes to be an identity-specific theology of liberation and has as its primary focus the struggles for liberation of Dalit communities. It is and has as its primary focus the struggles for liberation of Dalit communities. It is Dalits, but also as a political theology for social action towards the transformation of injustice and oppressive structures (Rajkumar 2010:1). 
growing academic influence of Christian Dalit theology as a form of contextual theology, whereas on the other we have the glaring discrimination of Dalits within Christianity as well as the continued passivity of the Church to engage in the issues of Dalit liberation. (p. 1)

Rajkumar (2010:2) quotes the following lines from Shroud, a poem by Dalit Marathi poet Baban Londhe, illustrating the inefficacy and hidden violence of words that merely talk about socio-cultural change:

On a plain so vast our eyes could not reach

They would make speeches to their hearts content

and shout out novel slogans,

blow a breath of hope on our over tired limbs.

At times, to our shanty towns they would come,

Careful not to rumple their ironed clothes

crossing over lands and alleys,

jumping across streaming gutters.

When they stopped beside our doors

we felt inexplicably moved.

Viewing our pitiable state they would say

'Truly this needs a socio economic cultural change,

the whole picture needs to be changed'.

Then we would sing their songs

in sonorous full-throated tones.

Acting innocuous, they would eat

the marrow of our bones.

Days passed by.

Darkness pressed from all sides.

We battled against sunshine and rain

and like fools awaiting salvation

we have stood our ground

and are sunk to the neck in mire.

But now they say plans are worked out

for our salvation

covering our wasted tombs

in a new shroud

with munificence!

The act of naming reality cannot fulfil the full spectrum of its task by merely mapping out contextual ramifications on the surface of our existence, expressing the need for change at this level alone and working with people as if they were passive, manipulatable objects in the process.

A theological theory that concerns itself with naming reality, with the aim on nurturing (and not neglecting) this reality, will also have to take the depth level of our existence into account. It will have to deal with the way our vision for life and our capabilities of committing ourselves to a certain course of action are channelled from the core of our existence, our hidden hearts.

It will ultimately concern itself with the renewal of our hearts by the grace of God.

\section{Perspectives on renewal of the heart from canonical Holy Scripture}

In this section the concept of heart as a descriptor for the innermost core of human life, in its renewal by God and in its impact on how we view life and interact with life, is explored from the canonical Holy Scripture. ${ }^{9}$

\section{The role of the heart as the innermost core of human life and its expressions}

In discussing the psychology of Paul, Ladd (1993:517-518) illustrates how the Pauline usage of kardia corresponds essentially with the biblical usage of the Hebrew word leb as a designator of the inner life of a person and the various dimensions of human activities (expressions of life) that spring from this innermost core of life: The heart is the seat of emotions and desires, both good and bad (Rm 1:24; 2 Cor 2:4). Kardia is described as the source from which humanity's intellectual activity and ethical judgement can be influenced to such an extent that it becomes lacking in understanding and incapable of sound judgement $(\mathrm{Rm} 1: 21)$. Without enlightenment of the 'eyes of the heart' (Eph 1:18), the Christians' hope cannot be understood. In a similar way kardia is used to describe the seat of the will, leading a person to impenitence on the one hand, or obedience on the other hand $(\operatorname{Rm} 2: 5 ; 6: 17)$. In order to get a hold on why a human being thinks in a certain way and decides to speak and act in a certain way, the active role of the heart of that person should be considered (cf. Witherington 1994:291). In order to understand what is on the surface level of human action and behaviour, that which lies beneath the surface and can be hidden from plain site must be taken into account.

\section{Renewal of the heart}

From a canonical perspective, the heart is in need of being renewed and sanctified as a space from which the effects of the graceful presence of the living God can flow into our lives. By the covenant presence and actions of God at the core of our being, a hardened heart and the rigid, divided, unrighteous expressions of life that flow from it can be opened up to a process of renewal - becoming a source from which a fountain of undivided and unpolluted love for God and fellow human beings can begin to flow. This need for renewal at the core of our humanity is expressed in the way a case is made for a 'new covenant' in biblical literature. Despite physical circumcision, the hearts of Israelites remained uncircumcised (Lv 26:41; Dt 10:16; Jr 9:25). According to Deuteronomy 30:6, God will circumcise the hearts of a future generation of Israel. Through his prophet Jeremiah God promises that He will make a 'new covenant'

9.The author's presumptions and methodological point of departure flow from a vision that the biblical canon (the books of the Old and the New Testament) form an vision that the biblical canon (the books of the Old and the New Testament) form an
authoritative body of Spirit-inspired texts in which God reveals Godself in his living authoritative body of Spirit-inspired texts in which God reveals Godself in his living
relationship with his covenant community and this world. By naming this body of literature canonical Holy Scripture the author sees himself part of an interpretative community that acknowledge Scripture as a determinate set of contingent texts whose employment by the community, as Kelsey (2009a:147-148) states, 'is the medium in, through, and under which God works to call the community into being; nurture and sustain it; and, when necessary, correct and reform the ways they seek in their common life to respond appropriately to God's way of relating with them.' Although the books of the Old and New Testaments were written by different authors over a span of more than 1000 years, the reader of this body of literature, in this approach, seeks the guidance of the Spirit to trace lines and of literature, in this approach, seeks the guidance of the Spirit to trace lines and contingent patterns that flow from the history of revelation as it is described in these books; patterns of promise and fulfilment; patterns of foreshadowing an realisation with the completed work of Jesus Christ as culmination point for thes redemptive historical lines (cf. Greidanus 1999:48). These patterns and lines are, in this approach to studying Scripture utilised for the formation of normative theory. (Seeking guidance for our lives in God's service according to a way that is perceived to represent the fullness of what God intends for our lives.) 
with Israel in which He will purify the Israelites and will write his Torah on their hearts (Jr 31:31-34; cf. 32:39-40). According to Ezekiel 36:26-27 it could even be expected that God will completely replace the heart and spirit of the Israelites with a new heart and new spirit (Stettler 2004:491).

Jesus pointed out the wickedness and violent, relationshipdestroying forces that flow from a 'hardened heart' (Mt 19:8; Mk 7:6; 10:5). With him the kingdom of God is inaugurated: sins are forgiven, hearts circumcised, and the Torah written in people's hearts so that they can begin to carry out God's will with a cleansed conscience (Rm 2:29; Col 2:11-23; Heb 10:16, 22; cf. Stettler 2004:492).

\section{The effect of renewal of the heart on the way we view life and interact with life}

What will be the effect of the renewal of the heart - in the context of the new covenant and in a time frame where the kingdom of God is in the process of being inaugurated - on the way we view life and interact with life?

In his theological reflection on the purity of heart in Jesus' teaching as described in Mark 7:14-23, Stettler (2004:493) points out how Jesus works with the contrast between purity that comes from outside (consumption of food according to the purity laws of the Old Testament with the idea that this act reminds us not to interact with anything that can defile us before God), and purity of heart (pure motives, words and deeds that flow from the inner life and can have a purifying effect on our interaction with our living environment). For Jesus, the purity which the Torah demands and guards points symbolically forward to the all-embracing purity of the kingdom of God; a purity that cannot be effected by outward and superficial observation of rituals (without the core of our existence and the motives and actions that flow from this core being involved), but can only be achieved by cleansing of the heart.

Jesus challenges his disciples to comply fully with his ethics now that the kingdom of God is dawning, in the same way that they will at its final revelation. He calls them already to live in the purity of the coming world - a purity which is essentially one of the heart, out of which all words and deeds go forth pure, and which is pure in an 'offensive' and 'contagious' sense [with a cleansing and clarifying effect on its life environment]. (cf. Stettler 2004:494)

It is clear from this kingdom vision that Christians should be mindful of their heart. When a role is visualised for Christians to be a blessing to this world, this blessing cannot be enacted from a life that is merely superficially devoted to God's will for our existence. When the heart is not minded and actively submitted to the cleansing work of the Spirit of Christ, we cannot present an unclouded, uncompromised account of the true life that God has in store for this world.

In the Sermon on the Mount Jesus visualises a new life for those who are drawn into the inauguration of the kingdom of God. By starting his sermon with the Beatitudes, Jesus expresses a surprising blessedness of life for people who were actively and violently suppressed and impeded by a discriminating religious system into thinking that nothing truly substantial can flow from their lives. In the sixth Beatitude, Jesus states: 'Blessed are the pure in heart, for they shall see God' (Mt 5:8).

The 'pure in heart' blessed in the sixth Beatitude, according to Kelsey's (2009b:803) interpretation, are those whose obedience towards God is undivided. This Beatitude demands not a certain quality in the privacy of subjective interiority, but an existential how, an orientation in action in and towards one's public proximate contexts that decisively shapes one's wanting, thinking, and feeling in such fashion that one is active for fellow creatures according to the law's commands. Purity of heart seems to open a level of unified connectedness with our proximate contexts that clearly supersedes an approach that merely objectifies our environment and isolates us from living contact with it. Reflecting on Jesus' teachings in the Beatitudes, Bourgeault (2008) concludes:

His whole mission can fundamentally be seen as trying to push, tease, shock, and wheedle people beyond the 'limited analytic intellect' of the egoic operating system ${ }^{10}$ into the 'vast realm of mind' where they will discover the resources they need to live in fearlessness, coherence, and compassion or in other words, as true human beings. (p. 37)

In the sixth Beatitude a life is visualised that culminates in 'seeing God'. Purity of heart is portrayed to be instrumental in opening up an unclouded vision of God. A cleaner heart leads to a cleaner vision of God. In his reflection on the mundum cor [pure heart], Augustine suggests that humans are to be seen as beings that have corporeal senses by which they can apprehend the physical world, as well as senses of the heart or the homo interior by which God, justice and beauty alone can be perceived. Throughout this life this perception of God grows, but only in the resurrection will it be complete enough to see God 'face to face'. In this life the perception of God is increasingly clarified by means of an ever-growing likeness to God. We become closer to God and more and more like God as the purification process of the heart progresses and the expressions of life that proceed from the heart increasingly resonate with God-likeness (Lootens 2012:63-65).

The development of perception that is opened up by means of seeing God with increasing clarity does not only have to do with a gradual purification from background impressions that restricted, objectified and polluted our cognitive field of

\footnotetext{
10.Bourgeault (2008:36) distinguishes between the 'egoic' system of perception (the cerebral way of thinking that has to divide the world up in different bits and pieces, in subject and object, in order to perceive it) on the one hand, and the unitive system of perception (as the wisdom tradition centres it in the heart) on the othe hand: 'In wisdom, the heart is primarily an organ of spiritual perception, a highly sensitive instrument for keeping us aligned, as we journey along the horizontal axis of our life in time, with the vertical axis of timeless reality: the realm of meaning value and conscience. The heart picks up reality in a much deeper and more integra way than our poor Cartesian minds even begin to imagine' In western tradition way than our poor, Cartesian minds even begin to imagine.' In western tradition we tend to speak of the difference between head and heart in a very clichéd and dualistic way; as if 'thinking with the head' has to do with rational, objective thinking and 'thinking with the heart' has to do with a non-rational, emotional way of making decisions. The heart's job, according to Bourgeault (2009:19), is to loo deeper than the surface of things, deeper than the jumbled, reactive landscape of our ordinary awareness, and to beam in on the deeper, ensheltering spiritua world in which our being is truly rooted. Jesus calls it the 'kingdom of heaven'.
} 
view. It is not merely a matter of purification from cognitive elements that restricted our field of view to such an extent that we were unable to imagine a way forward over what seemed to be unbridgeable chasms. It is neither merely a matter of purification from elements that impeded our scope to such an extent that we were only able to imagine a small circle of the fullness of life that God has in mind for us - restricted to a vague future, isolated from our current existence. It is also a matter of seeing (experiencing) the heart of God in its undivided commitment towards opening up this fountain of life with overflowing abundance through the redemptive work of his Son, Jesus Christ. This experiential seeing increasingly opens the core of our existence to integral, unified connectedness with our living environment, heartfelt compassion for others and unrestricted action in ministering the fullness of God's love to them (cf. Pearmain 2001:76).

\section{Naming and nurturing reality from a heart in the process of being renewed by the grace of God}

What, then, will be the implications of these perspectives on renewal of the heart, for our quest to name reality in such a way that the act of this naming will not lead to despondent self-isolation from reality, disillusionment with reality and the negligence of reality that inevitably flows from these dispositions?

What will need to change in the homiletic praxis that we visualise for our sermons and the prophetic actions that flow from these sermons? These changes must be made in order to reflect a kind of attunement with reality that is increasingly renewed into a rhythm that is starting to beat in sync with the heart of God. How can our acts of naming reality begin to reflect a nurturing disposition towards reality that is bent on cherishing our proximate contexts with the eye on the abundant life it is destined for?

When we prayerfully place ourselves under the sanctifying work of the Spirit of Christ - asking for hidden and divisive motives of self-centredness and fears, regarding being overburdened by proximate contact with the 'untouchables' in society, to be cleansed from our hearts - a new vision for our place in this world will begin to emerge. Rigid concepts regarding the unachievability of trying to transform deeply entrenched patterns in society, like those that caused unbridgeable chasms between the privileged (people who see themselves as having barely enough for themselves) and unprivileged (people who are made to believe that they have nothing and are nothing), will begin to fade as we progressively begin to see God's vision for this reality in its clarity and magnificence.

In a sermon with the title, 'A-cross-shattered church',11 Stanley Hauerwas (2009:73) refers to John Howard Yoder's

11.Preached for the Duke Divinity School in the University Chapel on 02 February 2005 and is based on readings from Micah 6:1-8, Psalm 15, 1 Corinthians 1:18-31 and Matthew 5:1-12. claim: 'The cross is neither foolish, nor weak, but natural'. This claim challenges the notion that nonviolence must necessarily be seen as unnatural and irrational, which is why we have to work so hard to secure peace in a violent world. Yoder's claim, according to Hauerwas, suggests that Jesus' cross challenges questions that ask how to get from here to there. The apocalyptic transformation of the world named by the cross means that the challenge is how the present world can be transformed to the reality that it should be:

Thus we are not asked to love our enemies in order to make them our friends, but we are called to act out of love for them because at the cross it has been effectively proclaimed that from all eternity they were our brothers and sisters. We are not called to make the bread of the world available to the hungry, we are called to restore the true awareness that it was always theirs. (Hauerwas 2009:75)

The implications of Hauerwas's sermonic wisdom are clear: Our naming of reality does not have to take its point of departure from the presupposition that we still have to try and bridge unbridgeable situations. This disposition will leave us in a situation where the heart from which we speak can easily become contaminated by doubts regarding the achievability of righteousness for the despised and marginalised. Becoming progressively aware of God's vision for this world from a heart that is in the process of being purified by God's grace, we can begin to name reality with a prophetic vision for a world where more than enough flows for all from the unrestrained heart of God as it is revealed through his redemptive grace in Jesus Christ. Sermons in which reality is named in this way will become like fountains flowing from uncompromised hearts, bringing living, purifying and clarifying waters for those who need to be liberated from their rigid and limited perceptions. It is also for those who have been led to believe that they have no place in this world and that they have nothing of significance to share with their fellow human beings.

Sermons like these will likely pave the way for the formation of the kind of dialogical prophetic communities ${ }^{12}$ proposed by Christian ethicist Stanley Hauerwas (1981, 1983), and missiologist David J. Bosch (1991). In these prophetic communities the gospel can be proclaimed from a position of shared vulnerability, bearing witness to the way the fountain of God's grace has shattered our rigid patterns of self-concern and rationalistic doubt. It is purifying our hearts from the bitterness of unworthiness and is opening up our existence

12. Hauerwas's concern, according to Graham (1996:115, 116), was to establish theological ethics as the discipline that fosters the development of authentic Christian character. He emphasised the idea that moral discourse has its foundations in the stories and self-understanding of autonomous Christian communities, rather than universal rational principles. A Constantinian relationship, whereby the church simply reflects the higher values of secular society, and seeks to serve its needs without challenging or questioning the validity of them, is abhorred. Instead the church exists to witness to a radical alternative, living in this world as a 'colony of heaven' (Hauerwas \& Willimon 1989). Kritzinger and Saayman (2011:178) analysing Bosch's mission praxis, concludes that he consciously elected not to work with dialectical or conflict model, which called on an oppressed group to rally around dialectical or conflict model, which called on an oppressed group to rally around the cause of their oppression in order to put pressure on their oppressors. He rather promoted reconciliary strategies, following the 'politics of Jesus' as expounded by John Yoder. This meant gathering together an alternative (and unlikely) prophetic community consisting of people from all sides of the conflict who affirm each other's humanity and start living the life of the future in the present. In this, Bosch saw the way of the cross that all Christians are called to follow. 
into nurturing our reality with the fullness of heavenly life being entrusted to us (cf. Hall 2010:36).

In these communities those members who are reckoned to be privileged members of the dominant system in secular society do not have to remain trapped behind guilt-ridden, self-preserving facades. They can become free to see and share the fullness of life that flows from the redeeming grace that God has opened up in their hearts. In these communities the presence of the Dalits of this world no longer has to be labelled problematic and their position in society no longer irredeemably marginalised behind walls of isolation and disdain. From a heart purified by the grace of God, the violent impact of the despised, unworthy, uneducated, untouchable categories in which the Dalits of this world have been named and framed can be transformed into accepting the new name and kingdom frame proclaimed to them by Jesus Christ. They can embrace the name of being made the blessed people for whom the riches of God's grace in Christ are destined. They can become free to touch what has previously been portrayed to be untouchable with the nurturing compassion of God flowing from their hearts.

\section{Acknowledgements}

This work is based on research supported wholly by the National Research Foundation of South Africa (Grant Number 91018). Any opinion, finding and conclusion or recommendation expressed in this material is that of the author and the NRF does not accept any liability in this regard.

\section{Competing interests}

The author declares that he has no financial or personal relationships which may have inappropriately influenced him in writing this article.

\section{References}

Armstrong, C. \& Fontaine, S.I., 1989, 'The power of naming: Names that create and define the discipline', Writing Program Administration 13(1/2), 5-14.

Barthes, R., 1972, Mythologies, Hill \& Wang, New York, NY.

Bosch, D.J., 1991, Transforming mission: Paradigm shifts in theology of mission, Orbis Books, Maryknoll, NY.

Bourgeault, C., 2008, The wisdom Jesus: Transforming heart and mind - a new perspective on Christ and his message, Shambhala Publications, Boston, MA.

Bourgeault, C., 2009, 'Centering prayer and attention of the heart', Cross Currents 59(1), 15-27. http://dx.doi.org/10.1111/j.1939-3881.2009.00057.x

Brueggemann, W., 2014, Reality, grief, hope: Three urgent prophetic tasks, Eerdmans, Grand Rapids, MI.
Childs, J.M. Jr., 2003, 'Enabling grace', in A. Resner Jr. (ed.), Just preaching - Prophetic voices for economic justice, pp. 35-46, Chalice Press, St. Louis, MO.

Colson, C.W. \& Pearcy, N., 1999, Developing a Christian worldview of the Christian in today's culture, Tyndale, Wheaton, IL.

Dingemans, G., 2010, Sporen van de verborgen God: Een theologie van de Geest, Kok, Kampen.

Eco, U., 1976, Theory of semiotics, Indiana University Press, Bloomington, IN.

Foucault, M., 1970, The order of things, Vintage, New York, NY.

Freire, P., 2007, Pedagogy of the oppressed, 30th anniversary edn., transl. M. Bergman Ramos, Continuum, New York, NY.

Gnanavaram, M., 1999, 'Preaching grace in the Dalit situation of India today', in J.M. McDaniel (ed.), Preaching grace in the human condition: 4th Biennial conference of Societas Homiletica, Washington, DC, United States, 27 February - 04 March, 1999, pp. 49-54. (Studia Homiletica 3).

Graham, E.L., 1996, Transforming practice: Pastoral theology in an age of uncertainty, Wipf \& Stock, Eugene, OR.

Greidanus, S., 1999, Preaching Christ from the old testament: A contemporary hermeneutical method, Eerdmans, Grand Rapids, MI.

Hall, G., 2010, 'Prophetic dialogue: A foundational category for Practical Theology' International Journal of Practical Theology 14(1), 34-46. http://dx.doi. org/10.1515/ijpt.2010.4

Hauerwas, S., 1981, A community of character, University of Notre Dame Press, Notre Dame, IN.

Hauerwas, S., 1983, The peaceable kingdom: A primer in Christian ethics, University of Notre Dame Press, Notre Dame, IN.

Hauerwas, S., 2009, A cross-shattered church: Reclaiming the theological heart of preaching, Brazos Press, Grand Rapids, MI.

Hauerwas, S. \& Willimon, W.H., 1989, Resident aliens: Life in the Christian colony, Abingdon, Nashville, TN.

Kelsey, D.H., 2009a, Eccentric existence: A theological anthropology, vol. 1, Westminster John Knox, Louisville, KY.

Kelsey, D.H., 2009b, Eccentric existence: A theological anthropology, vol. 2, Westminster John Knox, Louisville, KY.

Kritzinger, J.N.J. \& Saayman, W., 2011, David J. Bosch: Prophetic integrity, cruciform praxis, Cluster Publications, Dorpspruit.

Ladd, G.E., 1993, A theology of the New Testament, rev. edn., Eerdmans, Grand Rapids, MI.

Lootens, M.R., 2012, 'Augustine', in P.L. Gavrilyuk \& S. Coakley (eds.), The spiritual senses - Perceiving God in western Christianity, pp. 56-70, Cambridge University Press, Cambridge.

Ottoni-Wilhelm, D., n.d., Preaching vulnerability: Naming and neglecting reality - A global perspective, viewed 23 April 2014, from http://www.societashomiletica.org/upcoming/preaching-vulnerability-naming-and-neglectingreality/.

Pearmain, R., 2001, The heart of listening: Attentional qualities in psycho-therapy, Continuum Books, London.

Rajkumar, P., 2010, Dalit theology and Dalit liberation: Problems, paradigms and possibilities, Ashgate, Farnham.

Sandangi, H.S., 2008, Dalit: The downtrodden of India, ISHA Books, Delhi.

Siebers, T., 1988, The ethics of criticism, Cornell University Press, Ithaca, NY.

Stephen, A., n.d., Preaching vulnerability: Naming and neglecting reality - An Indian perspective, viewed 23 April 2014, from http://www.societas-homiletica.org/ upcoming/preaching-vulnerability-naming-and-neglecting-reality/

Stettler, C., 2004, 'Purity of heart in Jesus' teaching: Mark 7:14-23 par. as an expression of Jesus' basileia ethics', Journal of Theological Studies 55(2), 467-502. $\mathrm{http}: / / \mathrm{dx}$.doi.org/10.1093/jts/55.2.467

Tubbs Tisdale, L., 2010, Prophetic preaching: A pastoral approach, Westminster John Knox Press, Louisville, KY.

Witherington, B., 1994, Paul's narrative thought world: The tapestry of tragedy and triumph, Westminster John Knox Press, Louisville, KY.

Zimmermann, J., 2004, Recovering theological hermeneutics: An incarnationaltrinitarian model of interpretation, Baker Academic, Grand Rapids, MI. 